\title{
Midyat İlçesi (Mardin) Tarım İşletmelerinde Mercimek Üretim Maliyetinin Hesaplanmasi*
}

\author{
Köksal KARADAS $^{1 * *}$ Celal BAKÇI ${ }^{1}$ İbrahim Hakkı KADİRHANOĞULLARI ${ }^{2}$ \\ ${ }^{1}$ Iğdır Üniversitesi, Ziraat Fakültesi, Tarım Ekonomisi Bölümü, Iğdır, Türkiye \\ ${ }^{2}$ Iğdır Üniversitesi, Uygulamalı Bilimler Yüksek Okulu, Iğdır, Türkiye \\ (**Sorumlu yazar e-mail: kkaradas2002@gmail.com) \\ DOI: 10.17097/ataunizfd.384604
}

Gelis Tarihi: 01.02.2018

Kabul Tarihi: 20.04.2018

\begin{abstract}
ÖZ: $\mathrm{Bu}$ çalışmanın amacı Mardin ilinde Mercimek üretimi yapan tarım işletmelerinin mercimek üretim maliyetlerinin hesaplanmasıdır. $\mathrm{Bu}$ amaçla çalışmada Basit Tesadüfi Örnekleme yöntemine göre yapılan 110 anketten elde edilen veriler kullanılmıștır. Araștırma sonuçlarına göre mercimek üretim maliyetinde üretim masraflarının \%76,50'sini değişken masraflar ve \%23,50'sini sabit masraflar oluşturmaktadır. Değişken masrafların \%36,82'sini toprak hazırlı̆̆ı, \%32,56'sını bakım masrafları, \%26,04'ünü hasat harman masrafları oluştururken sabit masrafların \%90,00'ını tarla kirası oluşturmaktadır. Üreticiler $152,82 \mathrm{~kg} / \mathrm{da}$ ana ürün mercimek ve $110,83 \mathrm{~kg}$ /da yan ürün saman verimi elde etmișler, $1 \mathrm{~kg}$ mercimeği 1,58 TL'ye ve $1 \mathrm{~kg}$ samanı 0,60 TL'ye satmışlar, mercimek üretiminden 91,57 TL/da brüt kâr ve 25,08 TL/da net kâr elde etmişlerdir. Çiftçi, ürün fiyatının düşüklüğünden dolayı çalıșmanın yapıldığı yılda mercimek üretiminden yeterine kâr elde edememiștir. Bölge mercimek üreticisinin daha yüksek fiyatla ürün satabilmesi için örgütlenmesi sağlanmalı, mercimek üretiminde girdi ve prim desteğinin arttırılması gerekmektedir.
\end{abstract}

Anahtar Kelimeler: Mercimek, maliyet analizi, Midyat (Mardin)

\section{Determination of Lentil Production Cost in Agricultural Enterprises in Midyat District}

\begin{abstract}
This study aims to determine lentil production costs in lentil producing agricultural enterprises in Midyat District of Mardin province. Data gathered from 110 questionnaires conducted as to Simple Random Sampling Method were used in the study. According to the results of the study, $76,50 \%$ of lentil production costs consists of variable costs while the remaining $23,50 \%$ is constituted by fixed costs. $36,82 \%$ of variable costs are costs for soil preparation while $32,56 \%$ are maintenance costs and $26,04 \%$ are harvest costs. $90,00 \%$ of the fixed costs are field rents. Producers get a 152,82 kg/da yield on the main product, lentil, and 110,83 $\mathrm{kg} / \mathrm{da}$ yield of the by product, hay. $1 \mathrm{~kg}$ of lentil is sold for 1,58 TL and $1 \mathrm{~kg}$ hay is sold for 0,60 TL. Producers earned 91,57 TL/da of gross profit from lentil production and net profit of 25,08 TL/da. Due to low prices in the year of the study, producers could not make enough profits from lentil production. It is necessary to organize the region lentil producers to sell products at higher prices, to increase input and premium support for lentil production.
\end{abstract}

Keywords: Lentil, Cost analysis, Midyat (Mardin)

\section{GíRiş}

Kuru baklagillerden olan mercimek birçok yönden öneme sahip bir bitkidir. Tahıllara göre daha yüksek protein miktarına sahiptir ve iyi bir protein kaynağıdır. Vitamin ve mineral maddeler bakımından zengin olup tahıllarla beraber tüketildiğinde amino asit dengesini iyileştirmektedir (Pellet, 1988; Baysal, 1988; Özkaya vd., 1998). Bu bitki lif (posa) içeriğinin zengin olması nedeniyle açlı̆̆ 1 gidermekte, iştahın dengelenmesine yardımcı olmakta ve beslenmede önemli yer tutmaktadır. Mercimek; kemik gelişimi ve sağllğ 1 için gerekli olan kalsiyum (Ca), metabolizmada kan yapıcı özelliğe sahip olan demir $(\mathrm{Fe})$, sinir sisteminin etkin çalışmasında etkili olan B vitaminleri bakımından zengindir (Meiners et al., 1976; Augustin et al., 1981; Desphande and Damodaran, 1990). Ete göre çok daha düşük düzeyde yağ içermesinden dolayı kandaki yağ seviyesini düşürmekte ve damar sertliğine bağlı kalp hastalıklarının ve kalın bağırsak bozukluklarının önlenmesine yardımcı olmaktadır. Öte yandan insüline bağlı olmayan şeker hastalarının diyetinde mercimek yemeklerinin yer alması, kan şekerinin ve yağının düzenlenmesine yarar sağlamaktadır (Baysal, 1988). İçeriğindeki folik asit sayesinde doğumsal kusurların, kalp hastalıklarının ve osteoporoza neden olan kemik kırıklarının önlenmesini vb. birçok açıdan insan ağlığı için faydalıdır (Trowell et al., 1985). Mercimeğin tane/sap oranı 1/1,5 olup, saplarında $\% 13,7$ oranında protein bulunmakta ve hayvan beslenmesinde protein açığını kapatması bakımından 1 ton baklagil sapının 8 ton tahıl sapına eşit olduğu belirtilmektedir (Toğay ve Anlarsal, 2008).

2016 yılı itibarı ile dünya mercimek üretimi 6.315 .818 ton olup verim ise $115 \mathrm{~kg} / \mathrm{da}$ dir (FAO, 2016). Dünya mercimek üretiminde ilk siray1 1.978 .000 ton ile Kanada, ikinci ssray 1.100 .000 ton ile Hindistan alırken Türkiye 345.000 ton ile üçüncü sırada yer almaktadır. Türkiye'de 1980'li yıllardan sonra mercimek üretim miktarında büyük artış meydana gelmesi mercimeğin önemli bir ihracat ürünü olmasını sağlarken (Emeksiz vd., 2005), 2000 yllından sonra üretim alanında azalma ve verimde ise artış gözlenmiștir. 1991 yılında 537.000 ha olan Türkiye mercimek ekim alanı 2016 y1lında 235.474 ha seviyesine gerilemiş, aynı yıllar verim ise $82 \mathrm{~kg} / \mathrm{da}$ dan $150 \mathrm{~kg} / \mathrm{da}$ a yükselmiştir (TÜİK, 2016). 2013 yılında 178.542 ton mercimek ihracatı yapılarak Türkiye ekonomisine 167.814.000 \$ katkı sağlanmıştır (FAO, 
2013). Türkiye'nin yaptığ1 ihracat miktarı 2014 y1lında 182 bin ton, 2015 y1lında 218 bin ton ve 2016 y1lında ise 203 bin ton olurken ithalat miktarı ise 2013 yılında 11 bin ton iken 2016 y1lında 271 bin tona yükselmiştir. 2013 yılı mercimek fiyatı 1,96 TL/kg iken 2016 yılında 7,29 TL/kg'a yükselmiştir (Anonim, 2017). Ülkemizin daha fazla mercimek ihracatı yapabilmesi için verimi yüksek, kaliteli, teknolojik özellikleri ve besin öğeleri yönünden zengin mercimek çeşitlerinin yetiştirilmesi önem arz etmektedir (Akova, 1997). 2016 yılında Türkiye'de üretilen mercimeğin \%17,37'si (59.924 ton) Mardin ilinde üretilirken aynı ilde ortalama mercimek verimi $190 \mathrm{~kg} / \mathrm{da}$ olup Türkiye ve dünya ortalamasının üzerindedir (TÜIK, 2016). 1991 y1lında Mardin'de mercimek ekim alanı 1.137.440 dekar iken bu alan 2016 yılında 308.290 dekara gerilemiştir. Mercimek üretimi Türkiye'de olduğu gibi Mardin ilinde de azalmıştır. 2013 yılı Midyat ilçesinde üretilen mercimek miktarı Mardin mercimek üretiminin $\% 14,72$ 'si olup verim $179 \mathrm{~kg} /$ da dır. Çiftçinin daha fazla alanda mercimek üretebilmesi birim alandan daha yüksek miktarda ürün elde etmesi ilgilidir.

Daha verimli kullanılan kaynaklar birim alandan daha yüksek ürün elde edilmesine ve birim ürün maliyetlerinin azalmasına sebep olmaktadır (Karadaş, 2016). Tarım işletmelerinde faaliyet sonuçlarının ekonomik analizi açısından maliyet hesaplaması yapılmaktadır. Maliyeti etkileyen unsurlar olan fiyat ve verimlilik ekonomik ve doğal faktörlerden etkilendiği için zaman içerisinde değişiklik göstermekte olup maliyet hesaplamalarının da zaman zaman tekrar edilmesi gereklidir. Bu çalışmanın amacı Türkiye ve dünya ortalamasından daha yüksek verime sahip Mardin İli Midyat ilçesi mercimek üretim maliyetini belirlemektir. $\mathrm{Bu}$ kapsamda mercimek üretiminde kullanılan girdi miktarını ve değerini ortaya koymak, maliyeti oluşturan asıl unsurları belirleyerek üretim maliyetinin azaltılmasına yönelik önerilerin ortaya konulması amaçlanmıştır.

\section{MATERYAL VE YÖNTEM}

Materyal

Çalışmada kullanılan birincil veriler Mardin ili Midyat İlçesi'nde toplam 110 adet mercimek üreticisiyle yapılan anketlerden elde edilirken ikincil veriler ise konu hakkında önceden yürütülen ulusal ve uluslararası makale, rapor, istatistiki veriler, kayıtlar vb. den elde edilmiştir.

\section{Yöntem}

\section{Örneğe Girecek İşletmelerin Seçiminde Uygulanan Yöntem}

Araştırma popülasyonunu oluşturan işletmelerin belirlenmesinde Mardin İl Gıda Tarım ve Hayvancılık Müdürlüğü, Midyat İlçe Müdürlüğü Çiftçi Kayıt Sitemine (ÇKS) kayıtlı bulunan 4831 tarım işletmesi esas alınmış olup veriler 2013 yılına aittir. Örnek populasyondan anket yapılacak işletmelerin seçiminde işletmelerin mercimek ürettikleri arazi varlıkları dikkate alınmış ve Basit Tesadüfi Örnekleme Yöntemi kullanılmıştır.

İşletme arazi genişliği dikkate alınarak populasyonu temsil edecek işletme sayısı;

$$
n=\frac{\left(N S^{2} t^{2}\right)}{\left((N-1) d^{2}+S^{2} t^{2}\right)} \text { formülü kullanılarak elde }
$$
edilmiştir (Çiçek ve Erkan, 1996)

$\mathrm{n}$ : Populasyonu temsil edecek işletme sayısını, (4831),

$\mathrm{N}$ : Populasyondaki toplam işletme sayısını

$\mathrm{S}^{2}$ : Populasyonun varyansinı (1402),

t : \% 90 güven sınırlarında cetvel değeri $(1,65)$

$\mathrm{D}=\mathrm{kabul}$ edilebilir hata payı (Populasyon ortalamasının \% 10’u: 5,8)

$$
n=\frac{(4831 \times 1402 \times 2,72)}{((4831-1) 33,64+1402 \times 2,72)}=110
$$

Anket yapılacak işletme sayısı hesaplandıktan sonra ankete tabi tutulacak işletmelerin tespitinde tesadüfi sayılar tablosu kullanılmıştır.

\section{Anket Safhasında Uygulanan Yöntem}

Anket araştırıcının planladı̆̆ı yönde soruları belirleyerek incelediği değişkenlere göre veri toplanmasını sağlayan bir yöntem olduğundan tercih edilmiştir (Karadaş, 2000). Araştırmanın amacına uygun anket soruları konu ile ilgili daha önce yapılmış çalışmalardan yararlanılarak hazırlanmıştır. Anketlerde mercimek üretim maliyetinin hesaplanması amaciyla mercimek üretiminde kullanılan girdi çeşit, miktar ve fiyatları ile üretimde kullanılan girdilerin uygulama zamanları gibi sorulara yer verilmiştir.

\section{Anketlerin Analizinde ve Maliyet Hesabında Uygulanan Yöntem \\ Anket formlarının analizinde bilgisayardan} yararlanılmış olup SPSS 19 paket programı kullanılmıştır ve tüm verilerin dekara ortalaması alınarak analizler yapılmıştır. Maliyet unsurları olarak işçilik, materyal, arazi kirası, genel idare masrafları ve sermayenin faizi esas alınmıştır. Bir üretim periyodunda çalışılan tüm iş günleri anket verilerinden belirlenerek Erkek İş Günü olarak hesaplanmış ve aile işgücü için de yabancı işgücüne ödenen birim ücret dikkate alınarak bir gün için işçilik giderleri hesaplanmıştır. İncelenen işletmelerin mercimek üretiminde kullandıkları işgücü ile günlük yevmiye çarpılarak toplam işçilik masrafları hesaplanmış ve mercimek ekim alanlarına bölünerek dekara işçilik masrafi hesaplanmıştır. Tohum, gübre, ilaç vb. 
masrafların miktar ve birim fiyatları çarpılarak hesaplanmış dekara düşen materyal masrafları tespit edilmiştir. Ayrıca çuval, ip ve amortismanı hesaplanmayan araç ve gereçler (çapa, tırmık, kürek, vs.) için yapılan dekara masraflar ile taşıt kirası, işletmede kullanılan alet-makine için tamir ve üretimle ilgili diğer özel giderler de materyal giderlerinde incelenmiştir. Arazi kirası hesaplanırken kiracılıkla işletilenlere araziyi kaça kiraladıkları mülk olarak araziyi işletenlere ise arazilerini kaça kiraya verebilecekleri sorulmuş ve yıllık arazi kirası hesaplanmıştır. Genel idare masrafları hesaplanırken, değişken masraflar toplamının \% 3,00'ü esas alınmıştır (Güneş vd., 1990).

2013 yılında Ziraat Bankası tarafindan tarımsal ürünler için verilen kredinin yarısı \%4,8 sermayenin faiz karşılığ1 olarak alınmıştır (Bilgiç vd., 1983). İşçilik, arazi kirası, genel idare masrafları ve sermayenin faiz karşılığı toplamı tarla maliyeti olarak dikkate alınmıştır. Tarla maliyetine ürünü ambara taşıma, depolama, nakliye masrafları gibi pazarlama masrafları ilave edilmiş ve dekara mercimek için ödenen destek ve prim ödemeleri çıkarıldıktan sonra bulunan değer dekara elde edilen mercimek miktarına bölünmüş ve bir kilogram mercimeğin maliyeti hesaplanmıştır. Brüt kâr = Gayri safi (brüt) üretim değeri - Değişken masraflar ve Net kâr = Gayri safi (brüt) üretim değeri - Üretim masrafları formülleri kullanılarak hesaplanmıştır.

\section{BULGULAR}

Mardin ili Midyat ilçesinde mercimek üretimi yapan işletmelerden elde edilen anket verilerinin değerlendirilmesi yapılmış ve dekara mercimek maliyetini oluşturan unsurlar belirlenmiştir. $\mathrm{Bu}$ amaçla mercimek üretiminde kullanılan insan ve makine gücü, materyal miktarı ve değeri, uygulama sayısı ve birim maliyetleri hesaplanmıştır. 2013-2014 üretim dönemi birim fiyatlarına göre mercimek maliyeti 282,88 TL/da olarak hesaplanmıştır (Çizelge 1). Toplam üretim maliyeti içerisinde değişken masrafların oranı \%76,50 olarak belirlenirken, sabit masrafların oranı ise $\% 23,50$ olarak belirlenmiştir.

Daha önce yapılan çalışmalarda (Tüzün, 1993; Özel ve Gül, 2010; Altıntaş, 2014; Çıkman vd., 2016; Anonim, 2016a) değişken masrafların toplam masraflar içerisinde \%64 ile \%74 arasında değiştiğini belirlenmiş olup mercimek maliyeti ise $216,83 \mathrm{TL} / \mathrm{da}$ ve $243,87 \mathrm{~kg} / \mathrm{da}$ olarak bulunmuştur. Mevcut çalışmadan elde edilen sonuç daha önce yapılan çalışma sonuçları ile benzerlik göstermektedir. Değişken masraflar içerisinde en fazla payı $(\% 36,82)$ toprak hazırlığı ve bakım masrafları $(\% 26,04)$ oluşturmaktadır. Ulaşılan verim düzeyini bir taraftan üretimde kullanılan girdi miktarları diğer taraftan bunların uygulama zamanları etkilemektedir. Verimi doğrudan ekileyen girdilerin dekara uygulanma miktarları ve zamanları incelendiğinde toprak hazırlamada sürüm, tırmık ve tapan işlemleri sonbahar ve ilkbaharda ekim ve mart-mayıs ayları arasında yapılırken $2,47 \mathrm{lt} / \mathrm{da}$ yakıt ve 0,35 saat/da çekigücü, ekim işlemi nisan-mayıs aylarında mibzerle yapılıp $0,45 \mathrm{saat} / \mathrm{da}$ çekigücü ve $13,30 \mathrm{~kg} / \mathrm{da}$ tohum kullanıldığı belirlenmiştir.

Bakım işlemi için dekara 222,73 kg çiftlik gübresi, $15,96 \mathrm{~kg}$ kimyasal gübre ve $0,44 \mathrm{~kg}$ ilaç (herbisit) kullanılmış ve ekim-mart-nisan ve mayıs aylarında uygulanmıştır. Çıkman vd. (2016) mercimek üretiminde $18 \mathrm{~kg}$ tohum, $8 \mathrm{~kg}$ gübre ve 0,20 kg ilaç atıldığını, Tüzün (2014) 4,42 kg tohum, 5,62 $\mathrm{kg}$ gübre ve $0,09 \mathrm{~kg}$ ilaç kullanıldığını belirtmiştir. Çalışmada belirlenen tohum ve gübre miktarı daha önce yapılan çalışma sonuçları arasındadır. 


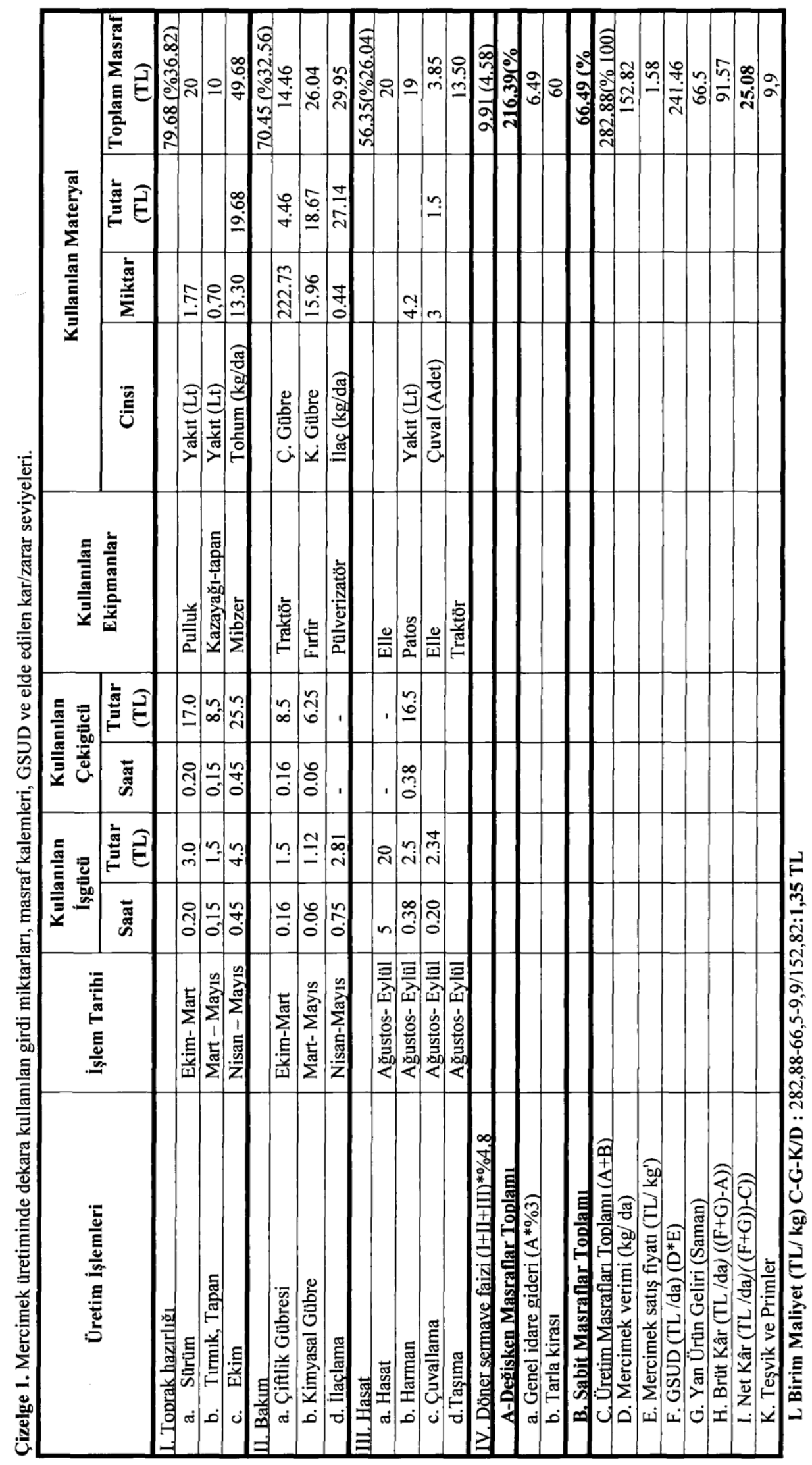


Hasat-harman işleri ağustos-eylül aylarında elle ve 5 saat/da olarak yapılmakta olup harmanda 4,2 lt/da yakıt ve 0,38 saat/da çeki gücü kullanıldığ1 belirlenmiștir. Değișken masraflar içerisinde en düșük payı $\% 4,8$ ile döner sermayenin payı almıştır. Üretim faaliyetine bağlı olmayan ve yapılması gereken sabit masrafların \%90'ını tarla kirası oluşturmaktadır. Mercimek maliyetinde tarla kirası daha önce yapılan çalışmalarda (Tüzün, 1993; Altıntaş, 2014; Çıkman vd., 2016) \%55-60 arasında belirlenmiştir. Anket çalışması yapılan 110 işletmenin 109'unun mercimek üretim arazisinin mülkiyeti şahsına ait olup tarla kirası bölgede 1 dekar arazinin kiralama fiyatı sorularak itibari sabit masraf olarak hesaplamaya dâhil edilmiştir. Bu çalışmada Midyat ilçesinde bir dekar araziden 241,46 TL değerinde 152,82 $\mathrm{kg}$ ana ürün mercimek ve 66,50 TL değerinde $166,25 \mathrm{~kg}$ yan ürün saman elde edildiği belirlenmiştir. Önceki yapılan çalışmalarda dekara mercimek veriminin 93,08 kg ile $176 \mathrm{~kg}$ arasında bulunurken (Tüzün, 1993; Togay ve Engin, 2000; Karabak ve Cevher, 2002, Aydoğan vd., 2008; Özel ve Gül, 2010; Altıntaş, 2014; Çıkman vd., 2016), Singh and Singh (2014) kuru şartlarda 45-65 $\mathrm{kg} / \mathrm{da}$ sulu şartlarda 200-300 kg/da verim alındığını bildirmiştir. Dekara mercimek verimi 2014 y1lı Türkiye ortalamasından (144 kg) fazla ve Mardin ortalamasında $(187 \mathrm{~kg})$ düşük olmasına karşın yeterli düzeyde verim elde edildiği tespit edilmiştir. GSÜD 241,46 TL/da olarak hesaplanmıştır. Üretici 1 dekardan 91,57 TL Brüt kâr ve 25,08 TL Net kâr elde ederken 1 kg kırmızı mercimeği 1,35 TL'ye mal etmiş ve 1,58 TL'ye satarak $\mathrm{kg}$ başına 0,23 TL kazanç sağlamıştır. Aynı yıl piyasada mercimek fiyatı 1,96 $\mathrm{TL} / \mathrm{kg}$ olduğu düşünüldüğünde tüketicinin ödediği paranın \%20'si aracıların eline geçmiştir. Bu çalışmada mercimek fiyatının düşüklüğü başlıca sorun olarak belirlenirken, 1985-2002 yıllarında Türkiye yemeklik tane baklagiller üretiminde ürün fiyatlarındaki değişimin, verimden daha fazla olduğu (Gündüz ve Esengül, 2004), mercimek yetiştiriciliğinde verim artırılması için erkenci çeşitlerin geç ekilmesinin uygun olacağ 1 (Temel vd,. 2012), nohut ve mercimek tarımını sinırlandıran en önemli faktörün ürün fiyatlarındaki düşüklük ve istikrarsızlık olduğu (Kabak ve Cevher, 2002) ve mercimek üretim ve pazarlamasında sorunların çözümü için bakliyat borsası kurulması gerektiği belirtilmiştir (Şahin, 2016). Ayrıca 1 dekar kırmızı mercimekten elde edilen GSÜD'ni Altıntaş (2014) 154,06 TL, Özel ve Gül (2010) 39,28 TL, Çıkman vd. (2016) 308,75 TL olarak belirlemiştir. Tokat ilinde yeşil mercimek üretiminde dekara $150 \mathrm{~kg}$ ürün alınırken $1 \mathrm{~kg}$ mercimek maliyeti $1,56 \mathrm{TL}$ ve satış fiyat $5 \mathrm{TL} / \mathrm{kg}$ olup 1 dekar mercimek üretiminden 516 TL net kar elde etmişlerdir (Anonim, 2016b).

\section{SONUÇ ve ÖNERILER}

2013 yılında Midyat ilçesinde (Mardin ili) mercimek üretimi yapan işletmeler üzerinde yapılan bu araştırmada mercimek üretiminde girdi kullanım miktarları ve birim maliyet hesaplanmıştır. Çalışma sonuçlarına göre; mercimek üretim maliyeti içerisinde değişken masrafların \%69,38'sini toprak hazırlığı ve bakım masrafları oluşturmaktadır. Özellikle toprak hazırlığında kullanılan gübre ve ilaç fiyatlarının yüksek olması değişken masrafları arttırmaktadır. 2013 yılında mercimek üreticilerine 4,3 TL/da mazot ve 5,5 TL/da gübre desteği yanında $10 \mathrm{kuruş} / \mathrm{kg}$ prim desteği verilmesine karşın (Anonim, 2013) bu miktarlar oldukça yetersiz kalmıştır. Mercimek üretim maliyetinin azaltılabilmesi için toprak hazırlığında be tohum ekimi için gerekli olan ilaç ve gübre girdilerine verilen desteğin arttırılması veya daha uygun fiyatla üreticiye verilmesi önerilebilir. Diğer taraftan daha düşük maliyetli olan çiftlik gübresi kullanımı yaygınlaştırılarak gübre masrafı azaltılabilir. Dekara 2-3 ton çiftlik gübresi uygulanması gerekirken, çalışmada dekara 222,73 kg çiftlik gübresi kullanımının yetersiz olduğu dikkati çekmektedir. Midyat ilçesi mercimek verimi $152,52 \mathrm{~kg} / \mathrm{da}$ ve mercimek samanı verimi ise $166,25 \mathrm{~kg} / \mathrm{da}$ olarak belirlenmiştir. Yeterli verim elde edilmesine karşın aynı yıl piyasada mercimek fiyatı $3 \mathrm{TL} / \mathrm{kg}$ olarak gerçekleşirken Midyat ilçesi üreticileri $1 \mathrm{~kg}$ mercimeği ortalama 1,58 TL'ye satmışlardır. Mercimekte pazarlama marjının yüksekliği gerek üreticiyi gerekse tüketiciyi mağdur etmektedir. Üreticilerin mercimek üretim ve pazarlamasında karşılaştığı sorunların çözümü için mercimeği de içine alan bir bakliyat borsasının ve kooperatif/birliğin kurulmasına ihtiyaç bulunmaktadır. Ayrıca mercimek yetiştirilen alanların haritasının çıkarılıp düşük verimli bölgelerde bunun nedenlerinin araştırılması son derece önemlidir.

\section{KAYNAKLAR}

Akova,, Y., 1997. Baklagiller. G1da Teknolojisi Derg., 2:88-91. Altıntaş, G., 2014. Tokat, Amasya, Yozgat ve Sivas yörelerinde yetiştirilen bazı tarım ürünlerinin 2013 yılı üretim girdileri ve maliyetleri. T.C. Gıda Tarım ve Hayvancılık Bakanlığı Tarımsal Araştırmalar ve Politikalar Genel Müdürlüğü Orta Karadeniz Geçit Kuşağı Tarımsal Araştırma İstasyonu Müdürlüğü Enstitü Yayın No: 261-P23, Tokat.

Anonim, 2013. Resmi Gazete, Bakanlar Kurulu Kararı http://www.resmigazete.gov.tr/eskiler/2013/04/201304085.htm (10 Şubat 2017).

Anonim, 2016a. Guidelines for Estimating Crop Production Costs 2016 in Manitoba. https://www.gov.mb.ca/agriculture/ business-and-economics/financial-management/pubs/cop_ crop_production.pdf (10 Haziran 2017).

Anonim, 2016b. T.C. TOKAT VALİLİĞİ Gıda, Tarım ve Hayvancılık İl Müdürlüğü, Bazı Tarım Ürünlerinin 2015 Yılı Maliyetleri. https://tokat.tarim.gov.tr/Belgeler/\%C4 \%B0statistikler/MAL\%C4\%B0YETLER/2015/TURHAL\% 20\%C4\%B0L\%C3\%87ES\%C4\%B0\%202015\%20YILI\%20 
T\%C3\%9CM\%20\%C3\%9CR\%C3\%9CNLER\%20MAL\%C 4\%B0YET\%C4\%B0.pdf (03 Mart 2018).

Anonim 2017. T.C. Tarım Gıda ve Hayvancılık Bakanlığı, Tarımsal Ekonomi ve Politika Geliştirme Enstitüsü, Tarım Ürünleri Piyasaları, Mercimek. https://arastirma.tarim.gov.tr/tepge (02 Mart 2018).

Augustin, J. Beck, C.B., Kalbfleisch, G., Kapel, L. C., Matthews, R. H., 1981. Variation in the Vitamin and Mineral Content of the Raw and Cooked Commercial Phaselous vulgaris Classes. Journal of Food Science, 46: 1701-1706.

Aydoğan, A. Karagül, V. Gürbüz, A., 2008. Farklı Ekim Zamanlarının Yesil ve Kırmızı Mercimeğin (Lens culinaris Medik) Verim ve Verim Öğelerine Etkileri. Tarla Bitkileri Merkez Araştırma Enst. Derg., 17:1-8.

Baysal, A. 1988. Türk Mutfağında Mercimek ve Nohut Yemekleri. Herkes için Mercimek Sempozyumu, 29-30 Eylül 1988, 17 26, Marmaris.

Bilgiç, E. Kaya, M. Ovayurt, K. Sarıkatipoğlu, S., 1983. Türkiye'de Üretilen Tarım Ürünlerinin Üretim Girdileri ve Maliyetleri Rehberi. T.C. Köy İssleri ve Kooperatifler Bakanlığı, Toprak $\mathrm{Su}$ Genel Müdürlüğü, Araştırma Dairesi Başkanlığı, Yayınları No:40, Ankara

Çıkman, A. Monis, T. İpekçioğlu, Ş., 2016. GAP Bölgesi'nde Mercimek Üretim Maliyetinin Tespiti Üzerine Bir Araştırma. 12. Ulusal Tarım Ekonomisi Kongresi, 25-27 Mayıs 2016, Cilt 3, s.1757-1762, Isparta,

Çiçek, A. Erkan, O. 1996. Tarım Ekonomisinde Araştırma ve Örnekleme Yöntemleri. Gazi Osmanpaşa Üniv. Ziraat Fak. Yayınları No: 12, Ders Notları Serisi No:6, Tokat.

Desphande, S.S. Damodaran, S., 1990. Food Legumes: Chemistry and Technology (Y. Pomeranz editör). Advances in Cereal Science and Technology. American Association of Cereal Chemists, Incorporated. St. Paul, Minnesota, USA, p.147241.

Emeksiz, F., Albayrak, M., Günes, E., Özçelik, A., Özer, O. O., Taşdan, K., 2005. Türkiye'de Tarımsal Ürünlerin Pazarlama Kanalları ve Araçlarının Değerlendirilmesi. Türkiye Ziraat Mühendisliği 6. Teknik Kongresi, Cilt II, s. 1155-1171, Ankara.

FAO, 2013. Food and Agriculture Organization of The United Nations. http://www.fao.org/faostat/en/\#data/TP (05 Eylül 2017).

FAO, 2016. Food and Agriculture Organization of The United Nations. http://www.fao.org/faostat/en/\#data/QC (03 Mart 20187).

Gündüz, O. Esengül, K., 2004. Türkiye Yemeklik Tane Baklagiller Üretiminde Verim ve Fiyat Riski, Gaziosmanpaşa Üniversitesi, Ziraat Fakültesi, Tarım Ekonomisi B. GOÜ Ziraat Fak. Derg., 21:33-41.

Güneş, T. Kıral, T. Bülbül, M. Vural, H. Tatlıdil, H., 1990. Başlıca Tarım Ürünleri. Araştırma Projesi. Ankara Üniv. TMO Alkasan Matbaası, Ankara.

Karabak, S. Cevher, C., 2002. Orta Anadolu Bölgesinde Nohut ve Mercimek Tarımını Sinırlandıran Sosyo-Ekonomik Faktörlerin Tespiti. Tarla Bitkileri Merkez Araştırma Enstitüsü Derg., 11:99-119.
Karadaş, K., 2000. Erzurum İlinde Patates Üretim Ekonomisi. Atatürk Üniversitesi Fen Bilimleri Enstitüsü, Yayımlanmamış Yüksek Lisans Tezi, Erzurum.

Karadaş, K., 2016. Ağrı İli Tarım İşletmelerinde Buğday Üretim Maliyetlerinin Hesaplanması. Alınteri Zirai Bilimler Derg., 31:33-41.

Meiners, C.R., Derise, N.L., Lau, H.C., Crews, M.G., Ritchey, S.J., And Murphy, E.W., 1976. The Content of Nine Mineral Elements in Raw and Cooked Mature Dry Legumes. Journal of Agriculture Food Chemistry, 24(6):1126-1130.

Özel, R., Gül, A., 2010. Tükiye'de Kırmızı Mercimek Üretim Ekonomisi. Türkiye IX. Tarım Ekonomisi Kongresi, s. 151158, Sanliurfa

Özkaya, B., Özkaya, H., Eren, N., 1998. Değişik Tarla Bitkilerinden Sonra Ekilen Bazı Mercimek Çeşitlerinin Pişme Kaliteleri ve Kimyasal Özellikleri. I. Verim, Bazı Özellikler ve Pişme Kalitesi. Gıda Teknolojisi Derg., 3(6):56-63.

Pellet, L.P., 1988. Lentils and Chickpeas in Human Nutrition. Herkes için Mercimek Sempozyumu, Bildiri Kitabı, s.87135, Marmaris.

Singh, K. M. Singh, A. K., 2014. Lentil in India: An Overview. SSRN Electronic Journal. https://www.researchgate.net/publication/266968749_Lentil in_India_An_Overview. (11 Temmuz 2017).

Şahin, G., 2016. 2016 Uluslararası Bakliyat Y1lı Hasebiyle Türkiye'de Mercimek (Lens culinaris Medik) Yetiștiriciliği, Atatürk Üniversitesi Sosyal Bil. Enst. Derg., 20(4): 16651696.

Temel, N. Eymirli, S. Aksoy, E., Arslan, F., Tetik, Ö., 2012. Kırmızı Mercimek (Lens culinaris Medic.)'te Sorun Olan Canavar Otu (Orobanche aegyptiaca Pers. ve O. crenata Forsk.) Mücadelesinde En Uygun Ekim Zamanı ve Çeşidin Belirlenmesi, Biyolojik Mücadele Araştırma İstasyonu Müdürlüğü, YYÜ Tar. Bil. Derg., 22(2):99-107.

Toğay, N., Anlarsal, E., 2008. Van Koşullarında Farklı Bitki Sıklıklarının ve Ekim Şekillerinin Mercimek (Lens culinaris Medic.)'de Verim ve Verim Öğelerine Etkisi. YYÜ Ziraat Fak. Tarım Bilimleri Derg., 18(1):35-47.

Togay, N., Engin, M., 2000. Van Kosullarında Sıra Aralığı ve Serpme Ekimin Mercimek (Lens culinaris Medic) Çeşitlerinde Verim ve Verim Öğelerine Etkisi. YYÜ Tarım Bilimleri Derg., 6(4):11-15.

Toowell, H. Burkitt, D. Heaton, K., 1985. Dietary Fibre, FibreDepleted Foods and Disease. Academic Press, London, England, 433p.

TÜiK, $2016 . \quad$ Türkiye İstatistik Kurumu. http://rapory.tuik.gov.tr/05-09-2017-11:59:432139497181545548297994922290.html? (15 Eylül 2017).

Tüzün, S., 1993. Polatlı İlçesi’nin Kuru Tarım Alanlarında Nadas Alanlarını Değerlendirmek İçin Yetiştirilen Başlıca Bitkisel Ürünlerin Maliyetleri ve Fiziki Girdilerinin Belirlenmesi. Ankara Üniversitesi Fen Bilimleri Enstitüsü, Yayımlanmamı̧ Yüksek Lisans Tezi, Ankara. 